\title{
Bioarte brasileira: \\ as poéticas da vida artificial
}

\section{LUCIANA HIDEMI SANTANA NOMURA}

\section{Resumo}

Esta pesquisa objetiva mapear a produção brasileira contemporânea de uma das correntes da ciberarte, a chamada bioarte, mais especificamente a vertente da “arte da vida artificial”. Essa vertente é inspirada nos processos dinâmicos dos sistemas biológicos, baseada em computação evolutiva que promove a emergência de sistemas artificiais, dinâmicos e autosustentáveis, denominados de vida artificial. A pesquisa ainda analisará as propostas poéticas destes artistas com ênfase na verificação das formas e níveis de interação destas obras, considerando as chamadas interação endógena, exógena ou mista. Paralelamente à investigação teórica será desenvolvida uma poética em bioarte que objetivará explorar as múltiplas possibilidades interativas de um sistema baseado em algoritmos evolucionários. 